\title{
ENLIGHTENMENT, CRITICAL THEORY, AND THE ROLE OF BUSINESS SCHOOLS IN THE ANTHROPOCENE
}

\author{
José Marcelo Maia Nogueira ${ }^{1}$ \\ Caio Coelho ${ }^{2}$ \\ Ana Carolina Aguiar ${ }^{3}$
}

\begin{abstract}
Purpose: This article analyses relations between the Dialectic of Enlightenment, critical theory, and the Anthropocene, and poses the question: How do the Dialectic of Enlightenment and critical theory relate to the Anthropocene? Moreover, what is the role of business schools and critical management studies in the context of the Anthropocene?

Theoretical framework: The Dialectic of Enlightenment questioned why advancements in rationality and technology failed to lead humanity to emancipation. Moreover, advancements in rationality and technology have led to the Anthropocene: a new geological age marked by the human capacity to modify the climate and ecosystems of Planet Earth. This debate, which is related to fields such as sustainability, organisations, and management, can be held in business schools.
\end{abstract}

Method/design/approach: To discuss this theme, we compose a theoretical essay.

Results and conclusion: The shock of the Anthropocene has provoked the need to think differently about social and environmental issues and to declare humanity as being responsible for nature. However, this response can neither be naïve nor generalised; it cannot place the responsibility for the Anthropocene on every human being equally. That would also reduce the significance of the hum an struggle to both acknowledge and solve the current climate and nature issues. We propose five dimensions where business schools could advance to foster critical thinking in the Anthropocene: curriculum, institutional practices, academ ic staff, the educational system, and subjectivity.

Research implications: Critical management studies (CMS) and business schools are two important players that can use the Anthropocene-induced perspective shift to think differently about social and environmentalissues.

Originality/value: We show that CMS can use the Anthropocene shock to reinforce itself and gain greater legitimacy to critically analyse modern methods of organising the human society. Business schools also need to review their current practices for educating future managers who need to be aware of their environmental impact both as human beings and as professionals.

Keywords: Anthropocene; Enlightenment; Critical Theory; Business Schools.

\footnotetext{
${ }^{1}$ Doutorando em Administração pela Fundação Getulio Vargas - FGV-EAESP, São Paulo (Brasil). Servidor Público do Poder Judiciário do Estado do Ceará (TJCE), Ceará (Brasil). Email: marcelomaia30@ gmail.com

${ }^{2}$ Doutorado em administração de empresas pela Fundação Getulio Vargas - FGV-EAESP, São Paulo (Brasil). Email: caio.rodrigues@fgv.br
}

3 Mestranda em Estudos Organizacionais pela Fundação Getulio Vargas - FGV-EAESP, São Paulo (Brasil). Email: aguiar.anacarol@gmail.com 


\section{ILUMINISMO, TEORIA CRÍTICA E O PAPEL DAS ESCOLAS DE NEGÓCIOS NO ANTROPOCENO}

\section{RESUMO}

Objetivo: Este artigo analisa as relações entre a Dialética do Esclarecimento, a Teoria Crítica e o Antropoceno, e tem como objetivo perguntar: Como a Dialética do Esclarecimento e a Teoria Crítica se relacionam com o Antropoceno? Além disso, qual é o papel das escolas de negócios e dos Estudos Críticos de Administração na discussão do Antropoceno?

Referencial teórico: A Dialética do Esclarecimento procurou questionar por que o iluminismo racionale a tecnologia falharam em cumprir sua promessa de levar a humanidade à emancipação. Por conta dessa falha, os avanços da racionalidade e da tecnologia contribuíram para o surgimento do Antropoceno, u ma nova era geológica marcada pela capacida de humana de modificar o clima e os ecossistemas do Planeta Terra. Esse debate está rela cionado a áreas c omo Sustentabilidade, Organizações e Gestão, pode ocorrer nas escolas de negócios.

Método: Para discutir esse tema, fazemos um ensaio teórico crítico.

Resultados e conclusão: O choque do Antropoceno provocou a necessidade de pensar de forma diferente sob re as questões sociais e de declarar a humanidade como responsável pela natureza. No entanto, essa resposta não pode ser ingênua nem generalizante; não pode a tribuir a responsabilidade pela época do Antropoceno a todos os seres hu ma nos de forma igual. Isso também reduziria a importância da luta humana para reconhecere resolver os problemas climáticos e naturais que enfrentamos. Nós propomos cinco dimensões nas quais as escolas de negócio poderiam avançar para cultivar o pensamento crítico no Antropoceno: Curriculum, práticas institucionais, professor, sistema educacional e subjetividade.

Implicações da pesquisa: Os Estudos Críticos em Administração (ECA) e as escolas de negócios são dois atores importantes que podem usar a mudança de perspectiva que o Ant ropoceno trouxe para pensar de forma diferente sobre as questões sociais e ambientais.

Originalidade/valor: O ECA pode usaro choque do Antropoceno para se reforçar e ganhar mais legitimidade e critic a r as formas modernas de organização. Isso inclui o surgimento de uma nova perspectiva de produção de conhecimento que considere seu impacto no sistema planetário. As escolas de negócios também precisam revisar suas práticas atuais. Eles são responsáveis por educar os futuros gestores que precisam estar cientes de seu impacto ambiental, tanto como seres humanos quanto como profissionais em organizações poderosas em nossa sociedade.

Palavras-chave: Antropoceno; Esclarecimento; Teoria Crítica; Escolas de negócio

RGSA adota a Licença de Atribuição CC BY do Creative Commons (https://creativecommons.org/licenses/by/4.0/). 


\section{INTRODUCTION}

The Dialectic of Enlightenment questioned the Age of Enlightenment during the eighteenth century regarding its promises that an emphasis on rationality would significantly improve human life (Horkheimer, Adorno, \& Noeri, 2002). This debate occurred after World War II, after and amidst the human drama caused by it. A question arose at that time: if rationality, technology, and technique were supposed to lead humanity to its emancipation, why did it not happen?

Analysis of that question revealed that although enlightenment in terms of rationality, technology, and technique expand human possibilities, develop human potential, and facilitate humanity's march towards a comfortable life, they also lead to greater subjugation and exploitation, both of nature and fellow humans (Horkheimer et al., 2002).

Evolution in terms of rationality, technology, and technique over the last few centuries also influenced the inauguration of a new epoch on Earth: the Anthropocene. This geological phase commenced when human actions began to significantly impact and modify the climate and ecosystems of the planet (Steffen, Crutzen, \& McNeill, 2007). Such modifications tend to be towards the degradation of nature. There is a link between the discussions regarding the Anthropocene and enlightenment, as both relate to the macro and planetary dimensions influenced by micro and everyday actions. Both forms of discussion make us rethink the concepts of rationality, technology, technique, human emancipation, exploitation, the domination of nature, etc.; these issues also permeate critical theory because they are related to the organisation of our society, where certain private companies hold greater economic power than many sovereign nations and shoulder serious social and environmental responsibilities. Therefore, critical management studies (CMS) and business schools can rely on the concept of the Anthropocene to enhance their perspectives.

The debate around the Anthropocene could proceed in different directions, depending on the area of science and knowledge in which it is set. Therefore, discussions in business schools becomes especially important when issues related to organisations, management, and sustainability are addressed. Other themes such as institutions (Ansari, Wijen, \& Gray, 2013), history (Perez, 2015), and organisations are being developed in face of the Anthropocene (Wittneben, Okereke, Banerjee, \& Levy, 2012). We approached the issue from the perspective of critical theory, as well as from that of business schools, believing that changes in the education and training of future managers constitute changes in the operating methods of current and future organisations (Banerjee and Arjaliès, 2021).

This article aims to draw a parallel between the Dialectic of Enlightenment and the concerns around the Anthropocene. While the Enlightenment did not lead to human emancipation, the Anthropocene may influence the search for alternative human behaviours (Wittneben et al., 2012). In that sense business schools and CMS are two communities that could use the Anthropocene to reinvent themselves and collaborate for emancipation, which is something usually addressed by critical theory (Alvesson \& Willmott, 1992).

The purpose of this study is to understand how the CMS and business schools in the Anthropocene can be a force for change in the future. Therefore, this article intends to: (1) present the similarities between the concept of the Anthropocene and the Dialectic of Enlightenment, and (2) show how business schools and CMS can influence the potential changes induced by the Anthropocene.

For this purpose, this research uses the theoretical essay approach (Bertero, 2011; Meneghetti, 2011), which entails critical review of literature and arguments construction based on previous research; it does not offer conclusions but provides ideas and arguments to foster discussions in the scientific community (Bertero, 2011; Meneghetti, 2011). This method is appropriate for questioning business schools, to investigate their role in this discussion, and 
understand how CMS can use the issues related to the Anthropocene to gain greater visibility in management and organisational studies. The Dialectic of Enlightenment highlighted the problems of the Enlightenment epoch. This essay proposes that the Anthropocene is an important topic to be debated in CMS and business schools. Researchers from CMS and business schools can consider the changes induced by the Anthropocene to discuss human emancipation. Finally, we propose five dimensions of advancement for business schools to foster critical thinking in the Anthropocene: curriculum, institutional practices, academic staff, the educational system, and subjectivity.

To achieve this objective, first we define the Anthropocene. Thereafter, we analyse certain concepts of critical theory related to the issues raised by the Anthropocene. Finally, we discuss the role of business schools and the need for a change of perspective.

\section{THE ANTHROPOCENE}

Planet Earth is estimated to be 4.5 billion years old; life on Earth, three billion years old; and human life, about 200,000 years old (Artaxo, 2014). Over this period, our planet has undergone countless transformations in both its crust and atmosphere, creating conditions for the emergence and flourishing of life itself. Life, in interaction with its environment, also modifies and transforms it. However, the speed of these transformations has never been faster than during the last century. After two centuries of industrialisation, globalised economic activity, and scientific advancements in medicine, engineering, and telecommunications, humans have not only intensified their exploitation of nature, but also grown at its expense. Relentless extraction of fossil fuels, destruction of forests and oceans, air and water pollution, unbridled production, and disposal of non-biodegradable materials, among other factors, place human activity today as a significant contributing factor to geological changes in critical processes of the planet (Artaxo, 2014). This phenomenon has resulted in the Anthropocene: a new geological age in which the planet operates beyond the limits of any previously known natural variability (Crutzen, 2002), generating unprecedented environmental, social, and economic challenges.

Coined in 1995 by the Nobel Prize winner in Chemistry, Paul Crutzen, the term Anthropocene only became internationally discussed after the year 2000 . It has yet to be formally voted upon, to be designated as a geological unit within the Geological Time Scale by the International Commission on Stratigraphy and by the International Union of Geological Sciences. However, many scholars already accept the existence of the Anthropocene and base their research on it.

The exact starting point of the Anthropocene is debatable. However, the Anthropocene Working Group of the Subcommission on Quaternary Stratigraphy, which is proposing that the Anthropocene be recognised as a geological epoch, suggests that it began in mid-20th century, as unprecedented population growth, industrialisation, globalisation, and humans-induced environmental changes are clearly identifiable around and after that point (Anthropocene Working Group, 2019). Despite this debate around its starting point, the evidence of the existence of the Anthropocene and the impact of human activity on the environment is overwhelming (Lewis \& Maslin, 2015).

The Great Acceleration is a cogent argument for the comprehension of our time as the Anthropocene. By plotting the graphs of social and economic trends of human life, such as population, GDP, energy and water use, and transportation and telecommunication, one can identify unprecedented growth in these areas post-1950s. These graphs were first published in 2004 and updated in 2010, showing the same increase in human activity on Earth (Steffen, Broadgate, Deutsch, Gaffney, \& Ludwig, 2015). That growth has been essential for both the economy and capitalism; however, it has proven to be unsustainable. Hence, the need for alternative ways of organising the society (Johnsen, Nelund, Olaison, \& Sørensen, 2017). 
After the Great Acceleration, climate and environmental issues could not be far behind. The increase in carbon dioxide emissions, global warming, climate change, the melting of the polar ice, oceans teeming with garbage, pollution, and deforestation now threaten the survival of our planet. The Anthropocene is marked by the consequences of human actions on nature (Dalby, 2014).

The negative impact of technological advancements by humans on nature is intertwined with the current organisation of human society and way of life. Thus, contemporary capitalism and corporatism are directly related to how private companies operate; ergo, the need to relate the Anthropocene to environmental management, sustainable development, systems theory, and management and organisations (Robinson, 2012; Wright, Nyberg, Rickards, \& Freund, 2018).

In July 2018, Wright et al. (2018) introduced this theme in the context of organisations in a special issue of the journal Organization. The concept of the Anthropocene has enthused the scientific community, being a central theme of several journals, such as Anthropocene, Anthropocene Review, and Elementa. According to the authors, the concept of the Anthropocene constitutes an important framework for the integration of knowledge and collaboration between different scientific fields. The concept also highlights the limitations of fragmented thinking between natural and social sciences. This is exemplified by the fact that these journals are inter- or trans-disciplinary.

The scientific premise that positions nature as an 'inhuman' object, separate from the humans who study it, is invalid because humankind is inseparable from nature. The human both constitutes and is constituted by nature. Thus, the concept of the Anthropocene opposes the fragmented view promoted by positivist science and the Cartesian thought. This fragmented perspective is highly responsible for the Anthropocene phenomenon itself (Wright et al., 2018).

By eliminating the categorical opposition of humans and nature, at the same time as revealing the farreaching influence of the former, the Anthropocene demands new reflection on ontological, epistemological, and methodological assumptions in Western society and the development of more integrated approaches to knowledge production (Wright et al., 2018,p. 457).

The Anthropocene could represent the possibility of a new scientific revolution. It can provide an opportunity to overcome a planetary crisis in a more coordinated and sophisticated manner. Wright et al. (2018) indicate the importance of the articulation between science and political engagement. For these authors, the questions raised by the Anthropocene concept have political implications, as we live in a globalised economy based on growth parameters. This concept, therefore, 'is at the center of a reorganisation of scientific endeavours, knowledge, and authority' (Wright et al., 2018, p. 458).

The Anthropocene concept calls humans to action. It demonstrates how humans affect nature and can cause what has been called 'the Anthropocene shock', which is supposed to change the human perspective of their relation to nature. Many people believe that highlighting it as a geological epoch can potentially change the purposes and focus of governments, corporations, and societies in general. This in turn is a call to people's subjectivity, that if our planet is at the risk of extinction because of human activities, humans must be aware of that and act accordingly. This change in subjectivity regarding the major concerns of our time is also fostered by the groups and organisations, such as business schools. Therefore, the change in people subjectivity, in business schools, is important due to the necessary change in our attention to the real issues that are threatening humanity.

Still, the Anthropocene is not a term that has been used without critique and reflection. For many critics, for example, it is still a social construct of the ruling scientific elites. Others question the linearity and reductionism of the general narrative surrounding this concept, which holds all humans responsible for today's environmental degradations, generalizing responsibility and the failures to respond. For such critics, the Anthropocene tragedy has already begun and is still driven 
by powerful and unethical social groups, such as the capitalist class, oligarchies, and nations at the centre of capitalism (Banerjee \& Arjaliès, 2021; Baskin, 2015; Malm \& Hornborg, 2014).

Banerjee and Arjaliès (2021) call for a decolonisation of the term Anthropocene, demonstrating that it is being used as a universal term, which only reinforces a history of colonisation, exploitation, and industrialisation. Most of the adverse environmental impacts are perpetrated by few groups, but the entire humanity is impacted-the most socially vulnerable groups, the worst. The discussion on elites is not exclusive to the Anthropocene, it is also related to democracy (Crouch, 2004), corruption (Andersson, 2017; Rodrigues \& Barros, 2020), economic growth, and crises (Faoro, 2012; Zald \& Lounsbury, 2010).

Banerjee and Arjaliès (2021) also propose that we decolonise the Anthropocene and use indigenous knowled ge to observe that Earth is alive and needs care. The term used is Gaia, as a new way for humans to relate to their planet. Using this term, we should not understand humans and nature as a dichotomy; rather, we must understand them. Following these ideas, business schools should pay greater attention to what it is been taught and how it has been taught to future managers. The solutions of the past may be invalid in the face of new environmental and social challenges, which necessitate changes in the curriculum and pedagogy of business schools.

This discussion is similar to those about ecological and climate problems. However, to delve into this, it is first important to investigate how critical theory fits into the debate about this new geological epoch (Banerjee \& Arjaliès, 2021).

\section{THE DIALECTIC OF ENLIGHTENMENT, CRITICAL THEORY, AND THE ANTHROPOCENE}

After the Enlightenment epoch, the belief emerged that new technologies and the centrality of reason in human life would improve the living conditions of humanity. In certain aspects, they did: today have better healthcare systems, longer life expectancy, solutions to hunger and povertyeven though certain problems still exist. However, our evolution in these aspects also comes at a cost: the degradation of the environment, and as a global society, we still have many issues to solve (Harari, 2014).

Over the last few centuries, the valorisation of rationality, technology, and technique produced changes in the planetary system that accelerated the environmental issues of the Anthropocene. Moreover, the benefits of this rationality do not reach everyone. Critical theory has been called upon to address this issue, to see what remains uncovered, and to propose solutions for existing social hierarchies and the human exploitation of nature (Kivivirta, 2018; Singer, 2018).

One of the criticisms of the Anthropocene proposition is that it puts the blame on humanity for the environmental disasters we have been facing. This means that humans become more than political and economic agents. We are all individually and morally responsible for atmospheric and ecological problems. What unites us as a species, puts all humans, independently from historical oppression, race, gender, or economic situation, in the same group. However, the exploitation of the earth, colonisation, race prejudice and other forms oppression were not made by all humans. Still all of us must endure the social and environmental consequences (Banerjee \& Arjaliès, 2021).

Global solidarities might therefore be determined by how much carbon one produces. In the Anthropocene, people at the same $\mathrm{CO} 2$ emissions level have more in common with each other than they do with anyone else. Difference of course still matters, [...] but unlike in the capitalist labour economy where only workers feel the harmful effects of a global process, in the Anthropocene all are adversely, if differentially, affected by $\mathrm{CO} 2$ emissions. Carbon emissions thus unite the species. This is the ultimate thread of solidarity — not citizenship, class, gender, language, religion, or region (Mikhail, 2016, p. 218).

The Covid-19 pandemic exemplifies how nations should discard their differences in the fight against a disease that affects everyone the same. On the one hand, the pandemic should unite 
all humans in the common fight against this disease; on the other hand, existing inequalities have been accentuated by the pandemic: poor people and poor countries have less access to good quality healthcare. Although the fight against Covid-19 involves everyone, yet some will be affected more than others. The same reasoning applies to the climatic changes in the Anthropocene epoch — with a difference: climate change affects the planet slowly; its timespan is much larger than the time taken by Covid-19 to spread around the globe (Nunes, 2020).

In this context, the role of institutions is extremely relevant. All institutions, not only those dealing directly with the disease, adapted to the challenges induced by the pandemic; for example, schools and factories changed their safety and sanitisation procedures. Likewise, the alarming message that accompanies the Anthropocene should cause institutional changes. In this sense, institutions such as business schools, which play important roles as think tanks and providers of future managers, must review their curriculum and pedagogy to assign greater centrality to environmental and social issues in the Anthropocene.

Critical theory, like the Dialectic of Enlightenment, question why our technological advancements did not lead to human emancipation. In the case of the Anthropocene, it gives us two perspectives. First, it puts the entire human species at the centre of the ongoing human problems. Second, researchers from the CMS must remember some sections of the human society contribute more to our problems than others, just like some sections of the human society bear a greater brunt of their consequences.

Current environmental issues call upon all countries for measures against pollution and ecological harm. However, calling upon a 'developed' country, which used the majority of global resources to gain that status, for such actions is different from calling upon an 'underdeveloped' country, which is still struggling with social issues such as poverty and hunger because their resources have been exploited by other countries. Ironically, most environmental conservation ideas are imported from modern Western countries, when focus should be on using indigenous solutions (Mawere, 2013). It is the role of critical researchers to highlight such issues (Banerjee \& Arjaliès, 2021).

Mawere (2013) gives an example of how the quest for domination persists in the pursuit of environmental conservation. He studied a case of conservation of insects in Zimbabwe. The religious and cultural uses of the insects are important, but this was causing an environmental issue. Neither scientific approaches nor indigenous epistemologies could effectively resolve the issue of extensive consumption of insects. Using indigenous and scientific methods separately-the scientific Western mindset dominating the indigenous - it was impossible to accommodate all interests in this case. They needed to join efforts equally to find a solution. Therefore, the author advocates a critical and broader thinking to assimilate multiple epistemologies and approaches. A constructive dialogue considering social hierarchies and human exploitation of nature would deliver positive solutions (Mawere, 2013).

Despite these social issues, the Anthropocene groups all humans together, even with the inequalities that divide them. For its part, critical theory covers multiple ontological and epistemological perspectives, and reserves space for approaches that, while criticizing social phenomena, possess the potential to question problems related to domination. One of these approaches is the Dialectic of Enlightenment (Horkheimer et al., 2002).

It questions the Age of Enlightenment regarding the expectations that rationality and technology would deliver progress to humanity. Proposed after the human tragedy experienced in World War II, it is guided by reflections such as: If rationality should have led humanity to its emancipation, why did it not happen? Moreover, why, in many ways, did the opposite happen?

According to Duarte (2002, p. 19), Horkheimer and Adorno do not regard the plight of humanity as a lost cause. They refer to the possibility of remembrance of nature in the subject to begin the process of reversing unilateral enlightenment, to make it dialectic. Based on this kind of dialectic, it can be noticed that enlightenment in terms of rationality enables the development of 
people's potential and a comfortable life, but also the domination and exploitation of both nature and other humans.

The contribution of Horkheimer et al. (2002) presents the dialectic as a means of breaking the unilaterality of enlightenment from a recollection of nature in the subject that leads us to perceive the relationships, tensions, and contradictions that exist between what we are and what we are not, not only in human, nature relations, but also in human-human relations.

In the Age of Enlightenment, mankind produced certain comforts, but also the conditions for the emergence of the Anthropocene. The process of civilizing, during which humanity progressively learnt to control nature for its benefit, also produced crass barbarism. This happened due to the unilaterality of thought, which has been occurring since the Stone Age (Duarte, 2002).

The CMS not only highlight the domination process, but also contribute to end this cycle (Alcadipani, 2021). Business schools from the global south are gaining scientific notoriety, decolonial researchers are publishing in relevant journals (Banerjee \& Arjaliès, 2021; IbarraColado, 2006; Mandiola, 2010), and critics of current research practices are highlighting the necessary changes that business schools should embrace because they are important political institutions in the Anthropocene (Barros \& Taylor, 2020; Cornuel, 2005). With this idea, the acceptance of the CMS in mainstream research centres and the hiring of critical scholars are important steps for bringing greater consciousness to science.

Although the questions inherent in the Anthropocene did not exist in this form in the reflections of Horkheimer et al. (2002), the attention to the problems caused by the separation between humanity and nature was already present in the Dialectic of Enlightenment.

Science is already aware of the existence of a new geological phase caused by human action. It is up to critical theory to updates reflections and foundations that could be used to consider the issues of the Anthropocene.

Enlightenment still recognizes itself even in myths. Whatever myths the resistance may appeal to, by virtue of the very fact that they become arguments in the process of opposition, they acknowledge the principle of dissolvent rationality for which they reproach the Enlightenment. Enlightenment is totalitarian (Horkheimeret al., 2002,pp. 3-4).

Horkheimer et al. (2002) used this example of myths, but also of antisemitism, to explain the Enlightenment as a totalitarian concept. Based on the reflection upon personal actions, humans learn to exploit nature and create social hierarchies. The Enlightenment appears as a means by which humans become aware of some aspects of reality and then assume dominion of the knowledge related to them. Once enlightened, the new normal becomes domination, which helps transform into natural that which should not be, and inhibits reflection on the status quo (Horkheimer et al., 2002).

These authors teach us that critical theory cannot be limited only to class struggles; it should also encompass common good. It can do that by working with a duality: on the one hand, be concerned about a large collective; on the other hand, be aware of issues related to minority groups, never forgetting the necessity of reflection and questioning, of doubting their situation, which is taken for granted. Critical theory must seek a better situation for all, considering all differences (Banerjee \& Arjaliès, 2021; Horkheimer et al., 2002).

Despite the importance of the Dialectic of Enlightenment and the discussions it has motivated, several questions remain unanswered: Why large-scale enlightenment has not occurred despite tremendous technological development? Should any supposed update to the Dialectic of Enlightenment maintain 'meanings of enlightenment' that refer to superiority? Could such an update no longer be based on something like a synthesis between light and dark, guided by enlightenment? Would it be something no longer unilateral, but dialectical? Could it be multi-, inter-, and trans-disciplinary, and finally, emancipatory? 
As expected, the role of critical theory is again necessary to ensure that the Anthropocene not turned into another totalitarian concept. In this sense, changes in the practices and composition of university staff by hiring critical researchers is important to maintain the tendency of critical reflexions upon new movements. As Alcadipani (2021) indicates, CMS researchers influence not only with their writings, but also by fostering critical thinking among students, by impacting communities, by introducing new and important issues such as sustainability and ethics, and by inspiring future generations.

Enlightenment and emancipation are important concepts for critical theorists. However, there has been a debate over whether emancipation should occur for everyone simultaneously, or occur progressively, with one group at a time. Alvesson and Willmott (1992) have defended micro emancipations. Based on post-structuralism, they proposed that this reflection would be neither radical nor global, that local emancipation, which questions the status quo, would be better accepted by the management field. These authors make a stand against utopic emancipation, seeking a possible and realistic one, reflecting on specific struggles and incidences of domination (Klikauer, 2015).

In the context of struggles between groups of people, which strongly influence our society, organisations form an area of focus. Companies and corporations have perpetrated most of the problems facing humanity today; they also are an integral part of the solution, given their power and relevance in the twenty-first century (Banerjee, 2008; Langenberg, 2004). Therefore, there is a need for critical studies in the management field, especially from the perspective of the Anthropocene.

\section{THE ROLE OF BUSINESS SCHOOLS IN THE ANTHROPOCENE}

The debate around the Anthropocene could proceed in different directions, depending on the area of science and knowledge in which it is set. Therefore, discussions in business schools becomes especially important when issues related to organisations, management, and sustainability are addressed.

Firstly, it is necessary to agree upon the objectives of business schools. Simply put, their purpose is twofold: cultivating future managers and producing scientific research. However, the manner in which these institutions achieve these objectives is debatable. Business schools can either teach ethics and responsibility to managers, or they also can mimic reality and preserve the current management practices (Cornuel, 2005; Gardiner \& Lacy, 2005). Similarly, the expression 'publish or perish' demonstrates the research objectives of business schools. While they can be groundbreaking studies, they also seek recognition through academic productivity and ranking, ignoring quality and contribution to literature (Davis, 2015; Miller, Taylor, \& Bedeian, 2011). Nevertheless, business schools are an important aspect of contemporary life, given the importance of corporations and business in modern-day society.

As Brenkert (1995) argues, corporations position themselves as part of the solution, when they are the cause of the problem. Critical management studies refer to an area within management that absorbs critical theory and discusses its issues. From an English origin, CMS unites different theoretical approaches under the same critical investigation. According to Mandiola (2010, p. 3), it includes 'Marxism, Foucauldian, feminist and post-feminist approaches, post-colonialist, postmodernist, and post-structuralist stand points'.

The CMS movement tried to create an identity and a political project, when, in fact, it encompasses different perspectives within the same group. Again, the duality of a great collective and small groups are present in the CMS field. Additionally, the CMS community is better accepted in most influential spaces, such as the Academy of Management and business schools (Reedy, 2008). It is known for researching critical issues and different perspectives related to the management of organisations (Alcadipani, 2021). 
The definition of the Anthropocene is derived from a sequence of debates and issues that have long been discussed. Discussing the role of business schools in the Anthropocene is another possibility in the CMS community, which has already dealt with topics such as ethics, corporate social responsibility, sustainability, and sustainable development (Shrivastava, 1995). Therefore, the role of business schools in the Anthropocene is questioned in a context where other debates have been conducted since the second-half of the 20th century.

Kivivirta (2018) states that the Anthropocene shock made management scholars and researchers realise that we should be more concerned about life on Earth. This shock could catalyse critical thought even in universities where it has not yet had an impact. To argue for the use of critical thinking when conducting research on the consequences of the Anthropocene, the author uses the example of the Arctic University that has received an increase in funding because of the new environmental perspective (Kivivirta, 2018). This example shows the need for critical thinking and research, given the irrefutable evidence of melting of the polar ice. Thus, the Anthropocene has brought environmental issues to the forefront of all research, and, as in the Arctic University, critical thinking is key to finding sustainable solutions.

In this broader context, the debate on the role of business schools in the Anthropocene encompasses institutional and social dimensions. By discussing Enlighment, Critical Theory and Anthropocene, this article suggests changes in the curriculum, institutional practices, academic staff, educational systems, and the subjectivity of the people who operate business schools.

First, the curriculum of business schools is the easiest dimension to observe in terms of their role in the Anthropocene; however, this dimension is not always considered in discussions about the Anthropocene. A possible initial question to address this dimension includes: how are issues related to the Anthropocene presented (or featured) in the curricula of business schools? There could be courses to address the Anthropocene directly as well as transversely.

The pedagogy dimension focusses on content and the way knowledge is built into curricula. This dimension promotes novel thinking among students. If 'business as usual' causes negative socio-environmental impacts, 'education as usual' perpetuates this 'business as usual' mentality (Anand et al., 2004; Bennis \& O'Toole, 2005). The fragmentation of knowledge encourages departmentalisation in a company. This does not help students think in a complex, multi-, inter-, and trans-disciplinary manner (Koris et al., 2017). Furthermore, such fragmentation is also related to the idea that human beings are separate from nature: a question that is central to the Anthropocene. Thus, trans-disciplinary pedagogy focusses not only on curricular content, but also on the manner of relating different kind s of knowledge.

Second, regarding institutional practices that transcend curriculum, the following questions can guide our reflection: how do business schools deal with environmental and labour issues? What is the purpose of addressing the Anthropocene in the curriculum of business schools, if the practices of the same institutions have negative socio-environmental impacts? How can business schools work with other educational institutions to promote debate about the Anthropocene? How do they encourage research in this field? Moreover, how do they contribute to the problems faced in the Anthropocene epoch?

Third, regarding the academic staff of business schools, it is worth questioning their background to identify if they are qualified/able to deal with the issues raised by the Anthropocene. How deep is this debate among them? In case of this dimension, it is necessary to consider the multiple educational backgrounds and resulting perspectives of academic staff (Miller et al., 2011).

Fourth, the educational system in which business schools are positioned appears more as a macro dimension and varies depending on the region where the institution is located. It refers to the relationship between business schools and private companies. It is also necessary to consider the influence that business schools have on economic decisions regarding the Anthropocene, where they operate. 
Fifth, the dimension of subjectivity helps us critically analyse the existing pattern of higher education to incorporate the rationality bias, in the sense of developing itself mainly through theories, concepts, and methods. Hence, many aspects of human subjectivity are excluded from this perspective. Some questions can help stimulate the debate about the scope of subjectivity in business schools in the Anthropocene, such as: In the learning process, what is the place of dimensions related to the body, emotions, intuition, and arts in business schools and the Anthropocene? Usually, such questions are outside the rationalised process of higher education, and when they are part of this process, it is usually in a marginalised manner.

The more these dimensions are integrated into business schools, the better they will perform their role in the Anthropocene. It is about discussing complex processes, and integrated realities, without unilateralism, as the Anthropocene demands. Hence, it is possible to teach people not only to learn a certain subject, but also to think differently. That is, the people who build knowledge in a non-fragmented manner, who see themselves as not being separate from nature, are vital to the role of business schools and managers in the Anthropocene.

\section{CONCLUDING REMARKS}

This article refers to critical theory, the Dialectic of Enlightenment, and the Anthropocene together to discuss the role of business schools and CMS during the Anthropocene. The discussion leads to the understanding that these concepts can complement one another. On the one hand, the shock of the Anthropocene has provoked the need to think differently about social issues and to declare humanity as being responsible for nature (Kivivirta, 2018). On the other hand, this response can neither be naïve nor generalised; it cannot place the responsibility for the Anthropocene epoch on every human being equally. That would also reduce the significance of the human struggle to both acknowledge and solve current climate and nature issues.

Critical management studies and business schools are two important players in the context of the Anthropocene-induced perspective shift. The former can use the Anthropocene shock to reinforce itself, gain greater legitimacy, and critically analyse modern methods of organising the human society. This includes the emergence of a new perspective on knowledge production that considers its impact on planetary systems. Business schools also need to review their existing practices as they are responsible for cultivating future managers who need to be aware of their environmental impact both as human beings and as professionals in powerful organisations. This perspective shift is strategic in the sense that it needs to be addressed in the curriculum, in staff training, and more generally, in the general purpose of business schools.

From the academic perspective, this article discusses that the Dialectic of Enlightenment revealed how the rational and technological advancements during the Age of Enlightenment created a new normal and did not lead humanity to its expected emancipation. The same understanding can be applied to the Anthropocene, if the recognition, that humans are the central focus of this geological epoch, does not induce necessary changes in our society to solve the current social and environmental disasters. This recognition has the potential to lead humans to emancipation. However, its neglect can repeat the frustration of the expected enlightenment.

In terms of how the CMS movement and business schools can help discuss and promote solutions to the current environmental issues, we discussed the need to reinvent business schools' curricula to incorporate social and environmental concerns, change institutional practices to contribute to a sustainable impact, hire and train academic staff to be able to deal with pressing concerns. Academics, researchers, and professors must position themselves in relation to their institutional environment towards governments and private companies and develop critical thinking with a learning process centred in students' subjectivity. The impact of business schools in a society that is based on corporations must be acknowledged and acted upon. 
To emphasise the importance of viewing the Anthropocene critically, this article proposes increased use of CMS in business schools. However, CMS and business schools are not the only communities that need to address these issues. Other aspects of society, such as the way companies and political systems are organised, will need to analyse the Anthropocene shock from critical and emancipatory perspectives. Research on what other institutions need to change in order to address the emergent issues of the Anthropocene are in order, not only to guide those institutions but also to suggest better ways to negate a repeat of the frustration with the expected enlightenment in the past.

Although our research limits itself to an essayistic argument, it opens space for future research to deal with empirical issues such as how the concept of Anthropocene appear in the curriculum of business school and how their researchers are helping to find solutions to environmental issuers. Exemplary initiatives of business schools and CMS that deal with the problems of the Anthropocene must be researched. Some suggestions for empirical research with these initiatives would be fruitful to help the Anthropocene to lead humanity to emancipation rather than repeating the enlightenment debacle. Researching new pedagogy, new ways of organising business schools, and new sustainability programs will guide institutional and global changes. Research themes based on indigenous knowledge and decolonial paradigms could also be useful. Moreover, methodological choices, such as action research and other approaches that investigate the impact of business schools on environmental issues are needed.

\section{REFERENCES}

Alcadipani, R. (2021). What type of change are we seeking to do? A response to Martin Parker auto-critique. Organization, 135050842110612. https://doi.org/10.1177/13505084211061240

Alvesson, M., \& Willmott, H. (1992). On the Idea of Emancipation in Management and Organization Studies. The Academy of Management Review, 17(3), 432-464.

Anand, V., Ashforth, B. E., \& Joshi, M. (2004). Business as usual: The acceptance and perpetuation of corruption in organizations. Academy of Management Executive, 19(4), 9-23. https://doi.org/10.5465/AME.2005.19417904

Andersson, L. (2017). Of Great Vampire Squids and Jamming Blood Funnels: A Socially Constructed and Historically Situated Perspective on Organizational Corruption. Journal of Management Inquiry, 26(4), 406-417. https://doi.org/10.1177/1056492616670755

Ansari, S. (Shaz), Wijen, F., \& Gray, B. (2013). Constructing a Climate Change Logic: An Institutional Perspective on the "Tragedy of the Commons." Organization Science, 24(4), 1014-1040. https://doi.org/10.1287/orsc.1120.0799

Anthropocene Working Group. (2019). Results of binding vote by AWG Released. http://quaternary.stratigraphy.org/working-groups/anthropocene/

Artaxo, P. (2014). Uma nova era geológica em nosso planeta: o Antropoceno? Revista USP, 103, 13. https://d oi.org/10.11606/issn.2316-9036.v0i103p13-24

Banerjee, S. B. (2008). Corporate social responsibility: The good, the bad and the ugly. Critical Sociology, 34(1), 51-79. https://doi.org/10.1177/0896920507084623

Banerjee, S. B., \& Arjaliès, D.-L. (2021). Celebrating the End of Enlightenment: Organization Theory in the Age of the Anthropocene and Gaia (and why neither is the solution to our 
ecological crisis). Organization Theory, 2(4), 263178772110367. https://doi.org/10.1177/26317877211036714

Barros, A., \& Taylor, S. (2020). Think Tanks, Business and Civil Society: The Ethics of Promoting Pro-corporate Ideologies. Journal of Business Ethics, 162(3), 505-517. https://doi.org/10.1007/s10551-018-4007-y

Baskin, J. (2015). Paradigm Dressed as Epoch: The Ideology of the Anthropocene. Environmental Values, 24(1), 9-29. https://doi.org/10.3197/096327115X14183182353746

Bennis, W. G., \& O’Toole, J. (2005). How business schools lost their way. Harvard Business Review, 83(5), 96-104, 154. http://www.ncbi.nlm.nih.gov/pubmed/15929407

Bertero, C. O. (2011). Réplica 2 - o que é um ensaio teórico? Réplica a Francis Kanashiro Meneghetti. Revista de Administração Contemporânea, 15(2), 338-342. https://doi.org/10.1590/s1415-65552011000200012

Brenkert, G. G. (1995). "The Environment, The Moralist, The Corporation and its Culture." Business Ethics Quarterly, 5(4), 675-697. https://doi.org/10.2307/3857409

Cornuel, E. (2005). The role of business schools in society. Journal of Management Development, 24(9), 819-829. https://doi.org/10.1108/02621710510621321

Crouch, C. (2004). Post-Democracy. Polity.

Crutzen, P. J. (2002). Geology of mankind: the Anthropocene. Nature, 415(23).

Dalby, S. (2014). Rethinking Geopolitics: Climate Security in the Anthropocene. Global Policy, 5(1), 1-9. https://d oi.org/10.1111/1758-5899.12074

Davis, G. F. (2015). Editorial Essay What Is Organizational Research For? Administrative Science Quarterly, 60(2), 179-188. https://doi.org/10.1177/0001839215585725

Duarte, R. (2002). Adorno/Horkheimer \& A Dialética do Esclarecimento. Zahar.

Faoro, R. (2012). Os Donos do Poder (5ª). Globo.

Gardiner, L., \& Lacy, P. (2005). Lead, respond, partner or ignore: the role of business schools on corporate responsibility. Corporate Governance: The International Journal of Business in Society, 5(2), 174-185. https://doi.org/10.1108/14720700510562749

Harari, Y. (2014). Sapiens: Uma breve história da humanidade. L\&PM Pocket.

Horkheimer, M., Adorno, T. W., \& Noeri, G. (2002). Dialectic of enlightenment. Stanford University Press.

Ibarra-Colado, E. (2006). Organization Studies and Epistemic Coloniality in Latin America: Thinking Otherness from the Margins. Organization, 13(4), 463-488. https://doi.org/10.1177/1350508406065851

Johnsen, C., Nelund, M., Olaison, L., \& Sørensen, B. (2017). Organizing for the post-growth economy. Ephemera, 17(1), 1. 
Kivivirta, V. (2018). The shock of the Anthropocene and a margin of hope: On possibilities for critical thinking in the Arctic context. Ephemera: Theory \& Politics in Organization, 18(3), 659-671.

Klikauer, T. (2015). Critical management studies and critical theory: A review. Capital \& Class, 39(2), 197-220. https://doi.org/10.1177/0309816815581773

Koris, R., Örtenblad, A., \& Ojala, T. (2017). From maintaining the status quo to promoting free thinking and inquiry: Business students' perspective on the purpose of business school teaching. Management Learning, 48(2), 174-186. https://doi.org/10.1177/1350507616668480

Langenberg, S. (2004). Parrèsiastic stakeholders: A different approach to ethical institutions. Journal of Business $\quad$ Ethics, 39-50. https://doi.org/10.1023/B:BUSI.0000039398.96906.41

Lewis, S. L., \& Maslin, M. A. (2015). Defining the Anthropocene. Nature, 519(7542), 171-180. https://doi.org/10.1038/nature14258

Malm, A., \& Hornborg, A. (2014). The geology of mankind? A critique of the Anthropocene narrative. The Anthropocene Review, 1(1), 62-69. https://doi.org/10.1177/2053019613516291

Mandiola, M. P. (2010). Latin America's critical management? A liberation genealogy. Critical $\begin{array}{llll}\text { Perspectives on } \quad \text { International } & \text { Business, }\end{array}$ https://doi.org/10.1108/17422041011049978

Mawere, M. (2013). A Critical Review of Environmental Conservation in Zimbabwe. Africa Spectrum, 48(2), 85-97. https://doi.org/10.1177/000203971304800205

Meneghetti, F. K. (2011). O que é um ensaio-teórico? Revista de Administração Contemporânea, 15(2), 320-332. https://doi.org/10.1590/S1415-65552011000200010

Mikhail, A. (2016). Enlightenment Anthropocene. Eighteenth-Century Studies, 49(2), 211-231. https://doi.org/10.1353/ecs.2016.0002

Miller, A. N., Taylor, S. G., \& Bedeian, A. G. (2011). Publish or perish: academic life as management faculty live it. Career Development International, 16(5), 422-445. https://doi.org/10.1108/13620431111167751

Nunes, J. (2020). A pandemia de COVID-19: securitização, crise neoliberal e a vulnerabilização global. Cadernos de Saúde Pública, 36(5). https://doi.org/10.1590/0102-311x00063120

Perez, C. (2015). Capitalism, Technology and a Green Global Golden Age: The Role of History in Helping to Shape the Future. The Political Quarterly, 86, 191-217. https://doi.org/10.1111/1467-923X.12240

Reedy, P. (2008). Mirror, Mirror, on the Wall: Reflecting on the Ethics and Effects of a Collective Critical Management Studies Identity Project. Management Learning, 39(1), 57-72. https://doi.org/10.1177/1350507607085978

Robinson, N. A. (2012). Beyond sustainability: environmental management for the Anthropocene Epoch. Journal of Public Affairs, 12(3), 181-194. https://doi.org/10.1002/pa.1432 
Rodrigues, C. C., \& Barros, A. (2020). From Caciques and Godfathers to Second-Order Corruption. Journal of Management Inquiry, 105649262090178. https://doi.org/10.1177/1056492620901780

Shrivastava, P. (1995). The Role of Corporations in Achieving Ecological Sustainability. Academy of Management Review, 20(4), 936-960. https://doi.org/10.5465/amr.1995.9512280026

Singer, D. (2018). Molecular Red : Wark's Marxist-posthumanist perspective on the Anthropocene. Ephemera, 18(4), 831-836.

Steffen, W., Broadgate, W., Deutsch, L., Gaffney, O., \& Ludwig, C. (2015). The trajectory of the Anthropocene: The Great Acceleration. The Anthropocene Review, 2(1), 81-98. https://doi.org/10.1177/2053019614564785

Steffen, W., Crutzen, P. J., \& McNeill, J. R. (2007). The Anthropocene: Are Humans Now Overwhelming the Great Forces of Nature. AMBIO: A Journal of the Human Environment, 36(8), 614-621.

Wittneben, B. B. F., Okereke, C., Banerjee, S. B., \& Levy, D. L. (2012). Climate Change and the Emergence of New Organizational Landscapes. Organization Studies, 33(11), 1431-1450. https://doi.org/10.1177/0170840612464612

Wright, C., Nyberg, D., Rickards, L., \& Freund, J. (2018). Organizing in the Anthropocene. Organization, 25(4), 455-471. https://doi.org/10.1177/1350508418779649

Zald, M. N., \& Lounsbury, M. (2010). The Wizards of Oz: Towards an Institutional Approach to Elites, Expertise and Command Posts. Organization Studies, 31(7), 963-996. https://doi.org/10.1177/0170840610373201 